of imprisonment in combination with hard labor. Despite the lack of practical implementation, the 1779 Penitentiary Act was essential to further improve the operation of existing detention facilities and build new prisons throughout the country, but as a local initiative rather than a centralized reform.

Key words: William Eden, William Blackstone, the Hard Labour Bill, the Penitentiary Act 1779.

DOI: 10.36695/2219-5521.1.2020.14

УДК 340.1

\title{
Д.Ю. АКУЛЕНКО
}

Данило Юрійович Акуленко, аспірант Інституту держави і права імені В.М. Корецького НАН України* ORCID: 0000-0002-7410-8255

\section{ФУНКЦІОНУВАННЯ ТА РОЗВИТОК ГРОМАДЯНСЬКОГО СУСПІЛЬСТВА ВІДПОВІДНО ДО КОНСТИТУЦІЙНИХ ЗАСАД}

У даній статті досліджуються актуальні питання теоретичного та практичного базису громадянського суспільства в Україні. Особлива увага приділена конституційним засадам, відповідно до яких таке суспільство може розвиватися та функціонувати.

Слід наголосити на непересічному значенні Конституції для розвитку інституту громадянського суспільства в Україні. Адже Основний Закон - це не тільки основа всього законодавства, а й першооснова системи правових норм, на яку покладено функцію забезпечення можливості існування громадянського суспільства не лише як ідея, що має наближати державу до євроінтеграції, а й як відповідна система суспільноправових відносин, яка ефективно працює задля захисту права особи в нашій країні.

Постановка проблеми. Проблематика даного питання полягає в тому, що вже давно минув той час, коли захист і розвиток громадянського суспільства має бути пріоритетним завданням Української держави, закріпленим у головному нормативно-правовому акті. Втім, певні аспекти невизначеності Основного Закону не дають можливості розробляти нові ефективні спеціалізовані нормативно-правові акти, які б прискорили розвиток громадянського суспільства.

Аналіз останніх наукових досліджень. Питання щодо правових засад існування, функціонування, розвитку та подальшої долі громадянського суспільства неодноразово розглядалися багатьма видатними вітчизняними вченими. Зокрема, це: В.О. Батанова, А.Р. Крусян, Н.М. Оніщенко, Т.С. Подорожна, С.В. Пєтков, О.В. Скрипнюк, С.О. Сунєгін, Ю.С. Шемшученко. Варто зауважити, що не зважаючи на значну кількість наукових праць на тему громадянського суспільства, питання про вектор подальшого розвитку громадянського суспільства на основі існуючих і потенційних конституційних засадах все ще залишається дискусійним.

Формулювання мети статті. Метою роботи $є$ дослідження можливих важелів конституційного впливу задля досягнення остаточної мети кожної демократичної і правової держави - побудови ефективного громадянського суспільства з функцією саморегуляції.

Виклад основного матеріалу. На жаль, жодна з існуючих у світі держав не спроможна створити умови, в якій сама держава буде повністю позбавлена можливості утиску прав і свобод своїх громадян, що призводило і призводить до проявів протиправної поведінки та правового нігілізму.

Проте ми можемо окреслити собі чітку мету, яку можливо імплементувати в українських реаліях. На нашу думку, наразі такою метою є досягнення суспільством такого стану, в якому кожна особа незалежно від іiї ідей, переконань, національності, статі, релігійної належності володіла б можливістю захисту своїх прав, які гарантуються Конституцією та іншими нормативно-правовими актами, а головне, щоб кожна особа знала про можливості такого захисту і розуміла їх.

Тобто вважаємо, ми маємо усвідомлювати, що порушення прав так само є одним із побічних ефектів плюралізму думок, поглядів, ідей і течій, а без такого плюралізму не може існувати жодна демократичноправова система. Ми зобов'язані обрати шлях адекватного захисту прав і свобод людини в сучасних умовах.

T.С. Подорожна переконана, що громадянське суспільство - це деклароване Конституцією України загальне право бути різними. А завдання держави - забезпечити це право і цю можливість. Іншими словами, це суспільство вільних людей, свобода котрих захищена державою через Конституцію ${ }^{1}$.

Конституційний парадокс полягає в тому, що хоч розбудова правової держави, а отже й громадянського суспільства, i $є$ загальноприйнятим пріоритетом, але в головному нормативно-правовому акті держави визначення чи навіть згадки про громадянське суспільство не існує. Тож маємо прикру ситуацію в якій загальновідомий пріоритет є, але закріплений він опосередковано.

А.Р. Крусян вважає, що існуюча ситуація $\epsilon$ «правовим упущенням у контексті теорії сучасного українського конституціоналізму». Особливо враховуючи те, що саме відповідно до конституційних засад здійснюється розбудова Української держави як демократичної, враховуючи їі правову систему, структуру державних владних органів і органів місцевого самоврядування².

() Д.Ю. Акуленко, 2020

* Danylo Akulenko, Postgraduate student of V.M. Koretsky Institute of State and Law of the NAS of Ukraine 
Хоча юридичною наукою Конституція і визначається як Закон прямої дії, його ефективність здебільшого залежить від розуміння та підтримки носіїв права, яке Конституція закріплює. Це в свою чергу означає, що формування правової культури стане джерелом втілення усіх засад, ідей та напрямів, які закріплені, але подекуди ігнорується величезною кількістю суб’єктів правовідносин.

Наразі в Україні перебуває в стані реформування політико-правова система, за таким умов окремий наголос ставиться на створенні таких правових норм, які б утворювали адекватну діючу правову систему без недієвих та напівдієвих норм, систему з мінімумом колізій у національному праві. Такий період фактично посилює значущість і роль будь-якої конституційної норми, оскільки- це необхідне підгрунтя для забезпечення демократичності самого процесу реформування та норм, які будуть створені чи змінені внаслідок цього.

Конституція України була прийнята у червні 1996 р. і увібрала в себе багато чого з минулої епохи, яка фактично закінчилася з розпадом Радянського Союзу. Так, досвідчені правники (наприклад, С.В. Пєтков) вважають, що Конституція фактично була й залишається фундаментом для розбудови держави, в якій закладено загальні риси майбутньої правової держави і лише контури громадянського суспільства³.

Втім наразі у свідомості більшості громадян Конституція сприймається не як непорушна основа та фундаментальна доктрина, а як нормативно-правовий акт, який мав би працювати, але чомусь не завжди працює, особливо якщо йдеться про забезпечення прав громадян.

На думку Н.М. Оніщенко, впровадження самого принципу соціального та політичного балансу у взаємовідносинах держави і громадянського суспільства може стати основою для виправлення та кореляції нестабільної політичної ситуації ${ }^{4}$.

Українська держава переживає напрочуд багато політичних криз. На нашу думку, існує певний взаємозв'язок ефективності українського політикуму під час державотворення із низькою заінтересованістю громадян в участі в нових політичних партіях, які здатні згенерувати нові ідеї та політично-суспільні напрями. Така проблема виникає внаслідок того, що Конституція визначає політичні партії та рухи як самостійні суб'єкти, але недолугість спеціалізованих законів роблять їх інертними без приватного фінансування. I це враховуючи той факт, що державне фінансування партій існує, але воно вочевидь неефективне.

Наслідком вищевикладеного стає низька заінтересованість громадян брати участь у таких важливих для громадянського суспільства утвореннях, оскільки останні без кулуарного фінансування приречені в кращому випадку на мирні зібрання та акції протесту, без реальних важелів впливу.

Неоднозначною наразі $є$ й судова реформа, яка все ще не викликає довіри в більшості населення і не руйнує міфи про так зване українське «кривосуддя», але детальний аналіз може бути здійснений лише після повноцінного запуску Антикорупційного суду та Вищого суду з питань інтелектуальної власності.

Сучасні українські 3МI, мабуть, найкращий індикатор занепалості громадянського суспільства. Так, наразі його можна проілюструвати регіональним телеканалом, на що ніхто не звертає уваги, вважаючи за краще дослухатися до ЗМI, які належать українським магнатам.

Варто зауважити, що, на превеликий жаль, відносно невелика частина населення України розуміє надважливе значення становлення і функціонування громадянського суспільства. Решті ж притаманний більш стриманий внесок у суспільно-політичний лад, цей прошарок ще не пристосувався до демократичноправового режиму і відкритості суспільства. Досить часто ці люди вважають імперативний метод регулювання правовідносин, жорстку підпорядкованість, негласність та підкорення органам державної влади справедливими і правильними умовами існування, тому ідея участі у формуванні первинних осередків громадянського суспільства не $\epsilon$ популярною. Виникає замкнене коло, в якому заінтересованість та бажання участі в інституті громадянського суспільства напряму залежить від його ефективності в сучасних реаліях, але така дійсність в свою чергу залежить від кількісного і якісного складу учасників суспільно-політичних процесів у державі.

Впровадження наступних кроків підвищить ефективність громадянського суспільства і наблизить до вищезгаданої мети:

- підвищення політичної культури, яка дасть змогу особам користуватися правами та захистом цих прав повною мірою;

- підвищення ефективності судового захисту прав і свобод людини, формування високого рівня поваги до букви й духу закону;

- впровадження по всій території України громадянського виховання з елементами природного різнорівневого патріотизму, який заснований на повазі і любові до всіх осередків культурної спадщини, починаючи від первинного соціального осередку сім'ї;

- імплементація системи захисту свободи інформації, гласності та відкритості, яка буде балансувати із захистом суспільства і держави від інформаційних атак, розповсюдження фейкової i шкідливої інформації, а також із поширенням інформації, яка здатна підірвати громадський порядок або спрямована на зміну державного ладу. Підтримка взаємозв'язків з усім світом задля можливості дослідження інформації з різних джерел;

- розвиток суспільної політичної правосвідомості, подолання соціальної пасивності;

- розширення доступності послуг органів державної влади, створення новітніх платформ для забезпечення можливості участі громадян в управлінні і контролі резонансних суспільних ситуацій;

- підвищення значення ролі недержавних суб' єктів правовідносин, здійснення максимального роздержавлення в усіх можливих сферах суспільного життя, становлення й розвиток чинних інститутів громадянського суспільства незалежно від їх форм власності та мети створення;

- забезпечення сприятливих умов існування асоціацій, громадських організацій, регіональних ЗМІ, профспілок, благодійних фондів, споживчих товариств, патронатних організацій, клубів за інтересами тощо. 
Розвиток різних форм громадського самоврядування і самодіяльності. Корисним буде вивчення зарубіжного досвіду, зокрема відповідних правових моделей США;

- підвищення політичного впливу недержавних суб'єктів правовідносин; пільство;

- постійне удосконалення механізмів контролю, а також механізмів зворотного зв'язку держава-сус-

- підвищення значення ролі державнодотичних інститутів, які забезпечують громадянське суспільство;

- впровадження механізму ефективного фінансування та підтримки політичних партій, що дасть змогу бути рушійною силою для нових ідей та поглядів і створення адекватної незалежної багатопартійної структури.

Висновки. У зазначеній проблематиці слушною $є$ думка доктора юридичних наук професора О.В. Скрипнюка, який вважає, що «у демократичній державі конституція, маючи найвищий статус, виступає тією специфічною інстанцією, яка має вплив не лише на суспільство та громадян, а й на саму державу. Більше того, держава не має ні права, ні практичної можливості виносити будь-які розпорядження чи приписи щодо повноти реалізації конституційних норм, їх звуження або обмеження, оскільки конституція виявляється захищеною від будь-яких можливих проявів свавілля державної влади»5.

Завданням держави є регулювання правовідносин між особами, які дотримуються приписів правових норм, із одночасним зрозумілим та повним забезпеченням їх прав та свобод.

Конституція - не просто документ найвищої юридичної сили, метою якого є забезпечення охорони $\mathrm{i}$ захисту прав та свобод.

Тож, на нашу думку, наразі існує необхідність внесення змін до Конституції щодо положень, які стосуються функціоналу громадянського суспільства. Ми маємо забезпечити ширші можливості участі громадян у політичному житті держави як за формою, так і змістовно, наприклад, шляхом впровадження можливості дистанційної участі у виборах за допомогою смартфону, а не лише «морально застарілим бюлетенем»; підвищити рівень правової і політичної культури населення; підтримати формування інститутів громадянського суспільства на засадах економічної свободи.

Насамкінець варто зазначити, що Конституція повинна стати програмним кодом для усіх подальших нормативно-правових актів. Саме тому Основний Закон має бути модернізований, сучасний, спрямований на захист прав, свобод, інтересів громадян не лише декларативно, а й практично. Втім, варто бути дуже обережним, адже не можна припустити навіть думки про маніпуляцію щодо Основного Закону держави. Слід не забувати події Революції Гідності 2014 р., що є наслідок узурпації влади, задля якої свого часу зміни до Конституції слугували інструментом для посилення повноважень президента, централізації влади та придушення громадянського суспільства як такого, в усіх його проявах.

${ }^{1}$ Подорожна Т.С. Теоретико-прикладні засади конституціоналізації правової системи та модернізації Конституції України : монографія ; за ред. і з передм. проф. Н.М. Пархоменко. Львів : ПАІС, 2014. 308 с.

2 Крусян А.Р. Громадянське суспільство в Україні як передумова сучасного українського конституціоналізму: поняття і тенденції розвитку. Право України. 2014. № 4. С. 17-25.

3 Пєтков С.В. Народовладдя: від права радянського до права громадянського. Київ: Видавничий дім «Скіф», 2014. 56 с.

4 Оніщенко Н.М. До питання про пошук балансу у співвідношенні громадянського суспільства та держави. Право України. 2014. № 4. С. 55-62.

${ }^{5}$ Скрипнюк О.В. Конституція України та їі функції: проблеми теорії та практики реалізації. До десятої річниці прийняття Конституції України. Київ: Академія правових наук України, 2005. С. 53-54.

\section{Резюме}

Акуленко Д.Ю. Функціонування та розвиток громадянського суспільства відповідно до конституційних засад.

У статті висвітлено правові упущення чинного законодавства стосовно громадянського суспільства. Досліджено дискусійні питання вдосконалення Конституції та погляди видатних вітчизняних вчених. Зокрема, вказано на протиріччя існування пріоритетів розбудови держави і її правових інститутів з відсутністю чіткого закріплення та усвідомлення про громадянське суспільство бодай в широкому сенсі. Проаналізовано проблему правого і політичного нігілізму. Особливу увагу приділено пошуку вирішення ключових проблем, які заважають імплементації вже існуючих конституційних доктрин у життя. Визначено чіткі шляхи для подолання перепон, що заважають ефективному функціонуванню громадянському суспільству.

Ключові слова: держава, громадянське суспільство, економічна свобода, конституційні засади, недержавний суб'єкт правовідносин, політична культура, правовий нігілізм.

\section{Резюме}

Акуленко Д.Ю. Функционирование и развитие гражданского общества в соответствии с конституционными принципами.

В статье освещены правовые упущения действующего законодательства в отношении гражданского общества. Исследованы дискуссионные вопросы совершенствования Конституции и взгляды выдающихся отечественных ученых. В частности, указано на противоречие существования приоритетов развития государства и его правовых институтов с отсутствием четкого закрепления, а также осознания гражданского общества хотя бы в широком смысле. Проанализирована проблема правого и политического нигилизма. Особое внимание уделено поиску решения ключевых проблем, которые мешают имплементации уже существующих конституционных доктрин в жизнь. Определены четкие пути для преодоления препятствий, мешающих эффективному функционированию гражданского общества.

Ключевые слова: государство, гражданское общество, экономическая свобода, конституционные принципы, негосударственный субъект правоотношений, политическая культура, правовой нигилизм. 


\section{Summary}

Danylo Akulenko. Functioning and development of civil society under constitutional basis.

This article was studied the constitutional norms for civil society, which, in the author's view, should be the doctrinal basis for its functioning.

The question arises because of the critical need of society in legal and political movements for a European model of relations between the state and the citizen, the urgency is determined not only by the author's personal convictions, but also by the unstable situation inside the Ukrainian politics, according to which only anti-democratic pseudosocial post-Soviet movements have unity and one point of view. In such conditions, the uncertainty of the Basic Law does not leave an opportunity to develop new, more effective legal norms that could increase the effectiveness of civil society.

The scientific basis for this article were the works of V. Batanov, A. Krusyan, N. Onishchenko, T. Podorozhna, S. Petkov, O. Skripniuk, S. Sunegin, Y. Shemshuchenko.

The aim of the work is to study the possible instruments of constitutional influence to achieve the ultimate goal of each democratic and legal state - building an effective civil society with a self-regulatory function.

The analysis of the real situation inside the country shows that the level of efficiency of civil society is currently critically low. Indicators of this are the following negative socio-legal phenomena:

- legal and political nihilism;

- the dependence of the media on the so-called "tycoons";

- a small number of non-state entities of legal relations (organizations, foundations, unions, associations, federations, consumer societies, etc.) especially in sparsely populated rural areas;

- low level of labor protection and social guarantees;

- ineffective financing of political movements, parties and youth party cells;

- low level of civil self-identification in certain regions of the country;

- ineffective distribution of financial resources to state monopolies, which are unprofitable to preserve employment.

This article provides possible ways of overcoming problems which can positively affect the further development of interaction between society and the state with an integrated approach to their implementation and strike a balance between state influence and civil pressure, the purpose of which is to ensure a decent level of protection of the rights, freedoms and interests of citizens.

Key words: state, civil society, economic freedom, constitutional foundations, non-state legal entity, political culture, legal nihilism.

DOI: 10.36695/2219-5521.1.2020.15

УДК 342.731

\section{M.C. BACIH}

Максим Сергійович Васін, аспірант Львівського університету бізнесу та права, виконавчий директор Інституту релігійної свободи*

ORCID: 0000-0002-0096-223X

\section{ТЕРМІНОЛОГІЧНІ АСПЕКТИ КОНСТИТУЦІЙНО-ПРАВОВОГО РЕГУЛЮВАННЯ ДЕРЖАВНО-ЦЕРКОВНИХ ВІДНОСИН В УКРАЇНІ}

Віра і релігійні переконання займають важливе місце в житті багатьох людей, що обумовлює їхню потребу в єднанні з іншими одновірцями з метою спільного сповідання, відправлення релігійних обрядів, навчання та поширення своєї віри. Міжнародні договори, ратифіковані Україною, захищають свободу совісті та віросповідання як основоположне право людини, обмежуючи можливість державного втручання у внутрішні справи релігійних організацій, поважаючи їх право на автономію, самоврядність, власну ієрархічну структуру. У національному законодавстві імплементовано основні міжнародно-правові засади державноцерковних відносин, однак залишаються й деякі прогалини. Зокрема, наукового аналізу та перегляду потребує понятійно-термінологічний апарат, яким послуговується Конституція і законодавство України, визначаючи релігійні організації у якості суб'єктів державно-церковної взаємодії.

У ст. 35 Конституції України закріплено принцип державно-церковного відокремлення, який використовує одночасно два терміни: «церква» і «релігійні організації», що не відповідає принципу правової визначеності.

Метою цієї статті є здійснення теоретичного аналізу термінологічних аспектів конституційно-правового регулювання державно-церковних відносин та за його результатами вироблення практичних пропозицій для вдосконалення законодавчого регулювання державно-церковної взаємодії.

Проблематику понятійно-термінологічного апарату державно-церковних відносин у своїх дослідженнях розглядали Л.Д. Владиченко, Д.О. Вовк, Г.В. Друзенко, В.В. Костицький, А.Ю. Радченко, Г.Л. Сергієнко, Л.О. Филипович та інші науковці. Однак ця сфера потребує подальших наукових розробок з точки зору конституційно-правових засад взаємодії держави і релігійних організацій.

Термінологія, яка використовується в Конституції України, має засадничий характер для подальшого розвитку нормативно-правового регулювання цієї сфери суспільних відносин. 3 огляду на це, поняття «церк-

(C) M.C. Васін, 2020

* Maksym Vasin, Postgraduate of Lviv University of Business and Law, Executive Director of the Institute for Religious Freedom 